EESTI NSV TEADUSTE AKADEEMIA TOIMETISED. KEEMIA

ИЗВЕСТИЯ АКАДЕМИИ НАУК ЭСТОНСКОИ ССР. ХИМИЯ

PROCEEDINGS OF THE ACADEMY OF SCIENCES OF THE ESTONIAN SSR. CHEMISTRY

1987,36,

УдК $622.765: 622.364(474.2)$

Н. ШУВАЛОВА, А. ТАТАРСКИИ, Л. МАКАРОВА,

T. РАЧКОВСКАЯ, Н. РОДННА, Г. ФЕДОРОВ

\title{
ОБОГАТИМОСТЬ ФОСФАТНЫХ РУД РАКВЕРЕСКОГО МЕСТОРОЖДЕНИЯ
}

(Представил М. Вейдерма)

\section{1. Некоторые сведения о вещественном составе}

Характерными особенностями ракушечных руд Прибалтийского бассейна являются их относительно простой минеральный состав, обособленность фосфатных раковин и кварца, существенные различия физикохимических свойств разделяемых при обогащении минералов. В то же время руды содержат целый ряд примесей (карбонаты, сульфиды и оксиды железа), которые ухудшают технологические свойства и обусловливают необходимость разработки различных вариантов схем обогащения с учетом специфики перерабатываемого сырья.

Согласно классификации, разработанной Государственным институтом горно-химического сырья (ГИГХС), на участке Кабала Раквереского месторождения распространены «чистые» и магнезиальные руды. Последние занимают менее $30 \%$ площади и тесно связаны с доломитизацией, имеющей место на отдельных локальных участках месторождения. Наблюдается пространственная связь доломитизации с зонами трещиноватости.

В верхней части промпласта доломит крепко цементирует детритовый материал, в нижней же части широко распространены доломитовые конкреции.

В процессе дальнейших геологоразведочных работ пространственное положение магнезиальных руд будет детализироваться.

Для изучения закономерностей изменчивости продуктивности фоспласта была составлена «Карта продуктивности Раквереской площади».

Наиболее высокой продуктивностью фоспласт характеризуется в юго-западной части месторождения (участок Кабала) - 2,2-2,9 т/м², что значительно превышает эти показатели по другим месторождениям бассейна $\left(0,59 \mathrm{~T} / \mathrm{m}^{2}\right.$ на Кингисеппском, $1,1 \mathrm{~T} / \mathrm{m}^{2}$ на Тоолсеском).

«Чистые» руды изучены на примере проб II-Tp, VI-Tp, IX-Tp, при этом проба IX-Tp имеет среднее для участка Кабала содержание $\mathrm{P}_{2} \mathrm{O}_{5}$ при модуле магнезиальности 0,05 и железистости 0,07 .

Изучение вещественного состава показало, что основными породообразующими минералами являются фосфат $(30-60 \%)$, кварц $(30-$ $50 \%$ ) и железосодержащий доломит (до $11 \%$ ). В небольших количествах (до 0,5\%) отмечаются пирит, гидрооксиды железа, глауконит и другие гидрослюдистые минералы.

Фосфат находится в трех модификациях: раковины оболид, конкреции и пленочный. Раковинный фосфат, представленный франколитом, имеет желтовато-коричневую окраску, которая местами распределена очень неравномерно (в виде отдельных точек, пятен, прослоев), что связано с примесями гидрооксидов железа, органического вещества и др. 
Концентрируется такой фосфат, главным образом, во фракции уд. веса $+2,95 \mathrm{r} / \mathrm{cm}^{3}$.

Во фракции уд. веса $+2,7-2,95$ г/см³ отмечаются обломки фосфоритовых конкреций (галечек), состоящих из мелких зерен кварца, сцементированных фосфатным (с примесью гидрооксидов железа и глинисто-карбонатного вещества) цементом.

Незначительное (до $1,5 \% \quad \mathrm{P}_{2} \mathrm{O}_{5}$ ) содержание фосфата, наблюдаю-

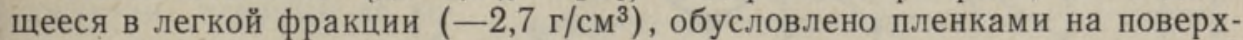
ности зерен кварца, фосфатные пленки обычно имеют прерывистый характер.

Основной вредной примесью, ухудшающей технологические показатели, являются карбонаты, представлены они главным образом доломитом.

Содержание $\mathrm{FeO}$ достигает $7 \%$, при пересчете химических анализов одной из карбонатных фракций получена теоретическая формула: $\mathrm{Ca}_{1,0}\left(\mathrm{Mg}_{0,8} \mathrm{Fe}_{0,2}\right)_{1,0}\left(\mathrm{CO}_{3}\right)_{2}$.

Отличительной особенностью доломита изучаемых проб является преимущественная его концентрация во фракции уд. веса $+2,95$ г/см что объясняется более заметным увеличением удельного веса доломита при изоморфном замещении магния железом, которое носит постоянный характер.

Доломит образует цемент карбонатных конкреций или отдельные кристаллические агрегаты. Карбонатные минералы входят в состав глинисто-карбонатных агрегатов, концентрирующихся в более легких фракциях, наряду с фосфатами образуют примазки по поверхности зерен кварца.

Соединения железа представлены гидрооксидами железа, пиритом, в виде изоморфной примеси железо входит в состав карбонатных минералов, а также участвует в строении глауконита и других гидрослюдистых минералов.

Количество пирита в изученных пробах незначительно (в среднем $0,2-0,3 \%)$, практически весь он концентрируется во фракции уд. веса

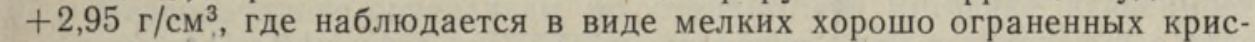
таллов, реже кристаллических агрегатов, единичные кристаллы пирита прослеживаются также на поверхности зерен кварца и среди карбонатного цемента.

Большинство гидрооксидов железа связано с фосфатом раковин, что придает ему коричневую окраску, небольшая часть образует примазки на поверхности зерен кварца, а также отмечается в виде отдельных агрегатов неправильной формы, реже оолитов и их обломков.

Силикаты железа входят в состав глауконита, который наблюдается в виде округлых зерен зеленого цвета, и участвуют в строении глинистых минералов.

Глинистые минералы присутствуют в составе глинисто-карбонатного цемента, чешуйками глин часто загрязнены карбонаты, железистые агрегаты.

Особенностью руды является наличие повышенного количества фосфата в классе $-3+1$ мм, содержание $\mathrm{P}_{2} \mathrm{O}_{5}$ в нем достигает $27 \%$. Однако наличие «трудных» граничных зерен +3 и -1 мм с низким содержанием $\mathrm{P}_{2} \mathrm{O}_{5}$ не дает возможности выделить эту фракцию в готовый продукт.

\section{2. Технология на основе применения анионных собирателей}

Выполненные в 1968-1983 гг. ГИГХСом исследования вещественного состава и обогатимости руд Тоолсе и Раквере позволили рекомендовать технологическую схему для обогащения низкомагнезиальных («чистых») 


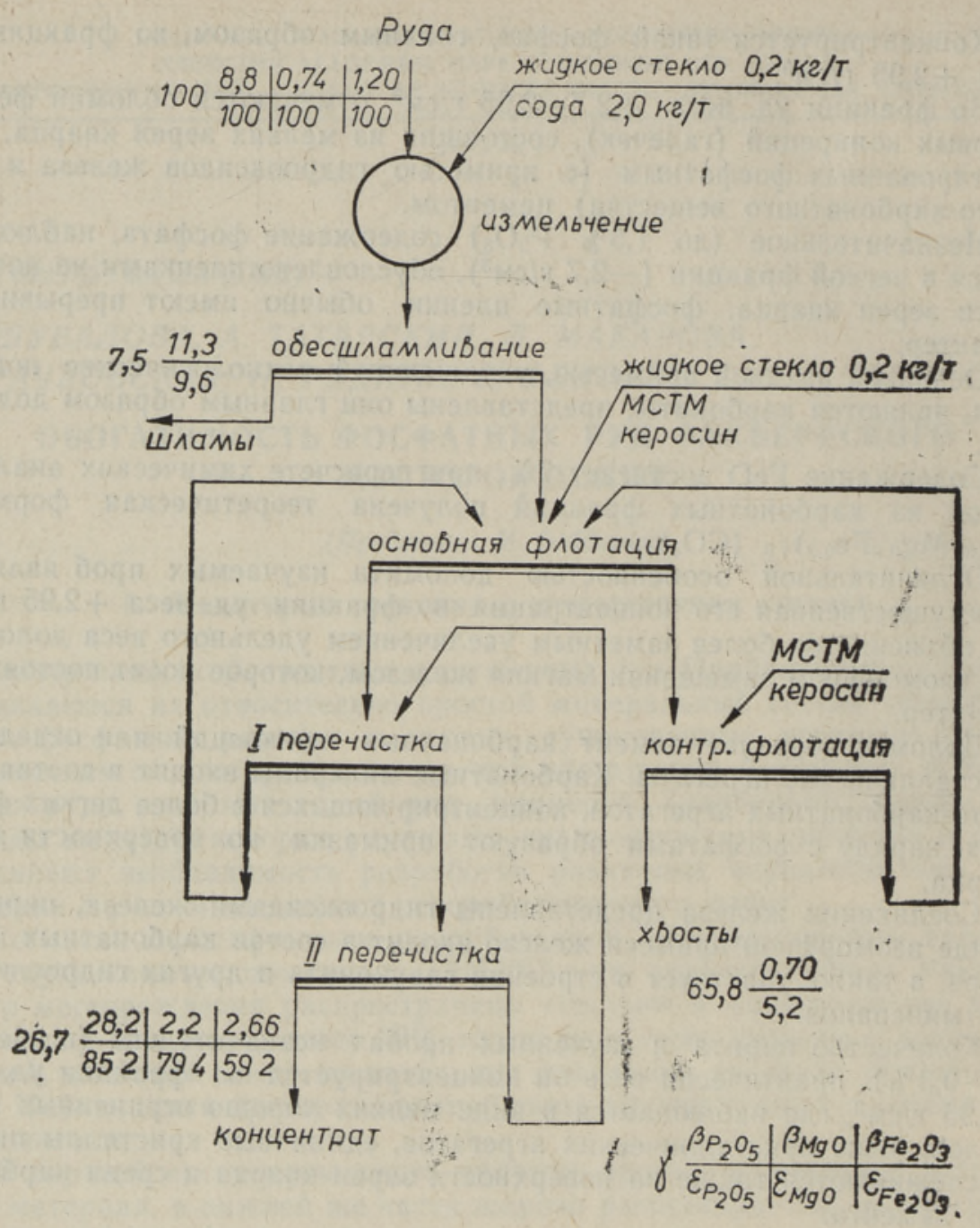

Рис. 1. Схема обогащения низкомагнезиальных руд. МСТМ - мыло сырого таллового масла.

руд, которая была заложена в проектные материалы по Тоолсескому фосруднику и временные кондиции на руду участка Кабала-Западный Раквереского месторождения. Схема аналогична применяемой при обогащении кингисеппских фосфоритов и заключается во флотации измельченной до крупности $0,3-0,4$ мм и обесшламленной по крупности 40 мкм руды талловым маслом и углеводородным собирателем в щелочной среде (рис. 1).

Из чистых руд получен концентрат (табл. 1), пригодный для промышленной переработки на экстракционную фосфорную кислоту и фосфорные удобрения.

Таблица 1

Химический состав концентрата, полученного из пробы IX-Tp

Компонент $\mathrm{P}_{2} \mathrm{O}_{5} \quad \mathrm{MgO} \quad \mathrm{CaO} \quad \mathrm{HO} \quad \mathrm{SO}_{\text {зсульф. }} \mathrm{SO}_{\text {зобщ }} \mathrm{Al}_{2} \mathrm{O}_{3_{\mathrm{Kp}}}{ }^{*} \quad \mathrm{CO}_{2} \quad \mathrm{~F} \quad \mathrm{Fe}_{2} \mathrm{O}_{3}$

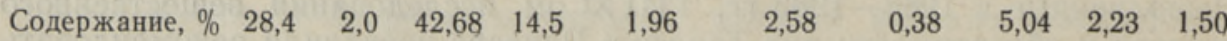

* кр - кислоторастворимое. 
Рекомендованная для проекта временных кондиций схема обогащения, несмотря на простоту, довольно высокую отработанность и надежность, имела вместе с тем и недостатки, главный из которых заключался в необходимости относительно тонкого измельчения руды перед флотацией, что требует высокого расхода энергетических ресурсов, дефицитных реагентов (таллового масла, керосина), а также может приводить к залипанию оборудования и трубопроводов на обогатительной фабрике.

Исходя из этого исследования 1984-1985 гг. велись в направлениях обогащения крупнозернистого материала и изучения возможностей применения катионной флотации.

Схемы и режимы обогащения крупнозернистого материала применительно к ракушечным фосфоритам с достаточной полнотой исследованы на руде Кингисеппского месторождения в лабораторных и полупромышленных условиях и показана возможность существенного повышения технико-экономических показателей $\left[{ }^{1,2}\right]$.

В целях изучения возможности обогащения грубоизмельченной руды месторождения Раквере проведены исследования при различной крупности измельчения.

Первоначально определяли по стандартной методике зависимость крупности продукта от времени измельчения руды в сравнении с рядовой рудой Кингисеппского месторождения (рис. 2). Из графика видно,

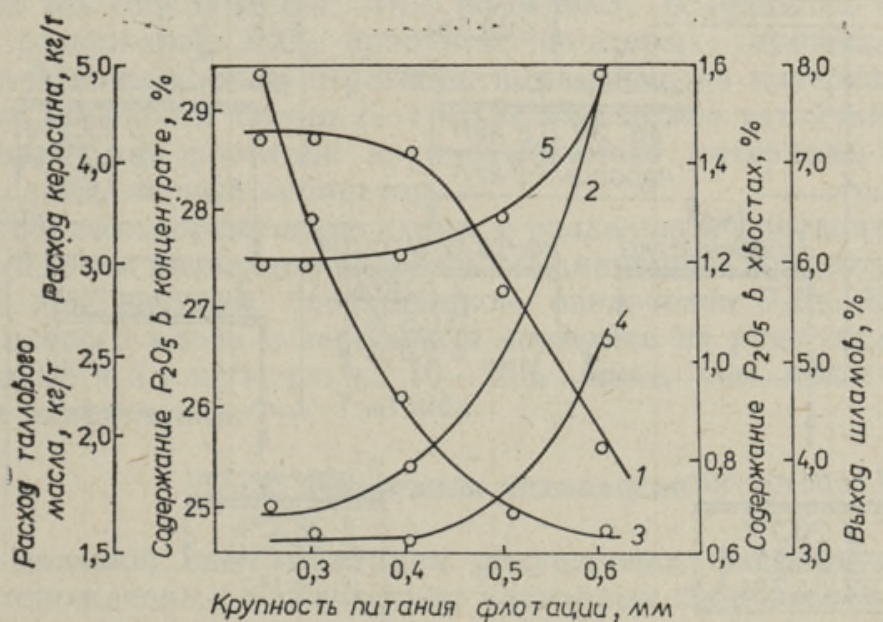

Рис. 3. Зависимость качества концентрата (1), содержания $\mathrm{P}_{2} \mathrm{O}_{5}$ в хвостах (2), выхода щламов (3), расходов таллового масла (4) и керосина (5) от крупности питания флотации полидисперсной пульпы. 
что измельчаемость пробы IX-Tр с учетом крупности исходной руды примерно на $15 \%$ выше, чем руды Кингисеппского месторождения.

Флотационные опыты при различной крупности измельчения (рис. 3) проводили по схеме, включающей основную и контрольную флотации и две перечистки концентрата. Температура пульпы $20-22^{\circ} \mathrm{C}$, $\mathrm{pH} 9-9,2$. Выяснилось следующее:

1. Оптимальные для данной схемы технологические показатели получены при крупности измельчения $0,3-0,4$ мм.

2. С увеличением крупности питания с 0,2 до 0,4 мм качество концентрата и операционное извлечение остаются на стабильно высоком уровне, а извлечение в кондиционный концентрат возрастает за счет снижения потерь со шламами, которые могут быть утилизированы как фосфатный продукт, что сократит потери $\mathrm{P}_{2} \mathrm{O}_{5}$ при обогащении.

3. Дальнейшее повышение крупности измельчения приводит к снижению качества концентрата и увеличению потерь $\mathrm{P}_{2} \mathrm{O}_{5}$ с хвостами флотации.

. Анализ химического и гранулометрического составов концентратов, полученных при флотации различного по крупности материала, показывает, что при флотации более грубоизмельченной руды тонкие фракции

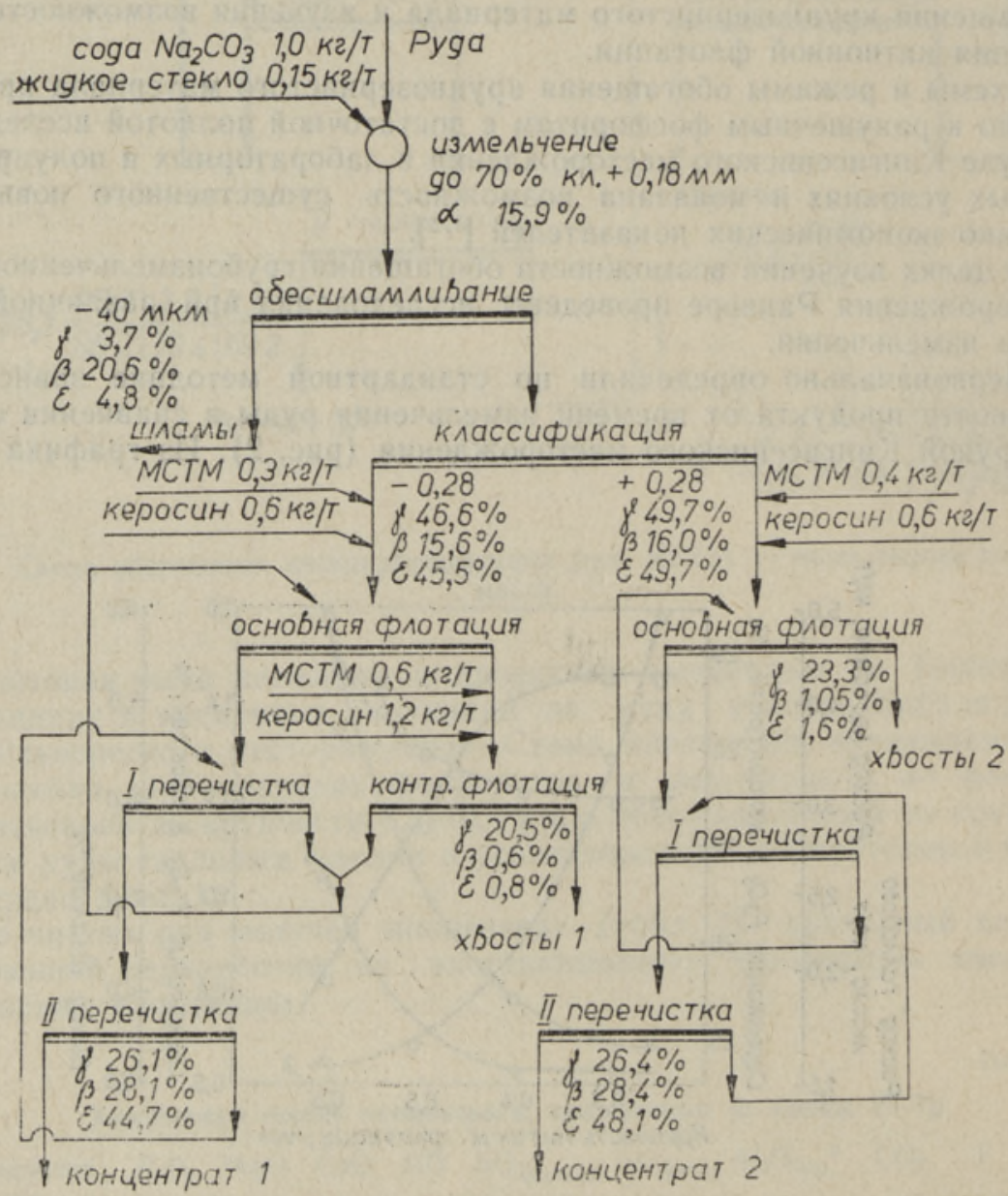

Рис. 4. Принципиальная схема обогащения фосфоритов Раквереского месторождения с раздельной флотацией фракций крупности. 
Результаты флотации классов крупности $+0,28$ и $-0,28$ мм

\begin{tabular}{|c|c|c|c|c|c|c|}
\hline \multirow{2}{*}{$\begin{array}{c}\text { Класс } \\
\text { круп- } \\
\text { ности, } \\
\text { мм }\end{array}$} & \multicolumn{2}{|c|}{$\begin{array}{l}\text { Расход реагентов, } \\
\text { кг/т }\end{array}$} & \multirow{2}{*}{ Продукты } & \multirow{2}{*}{$\begin{array}{l}\text { Выход, } \\
\%\end{array}$} & \multirow{2}{*}{$\begin{array}{c}\text { Содержа- } \\
\text { ние } \\
\mathrm{P}_{2} \mathrm{O}_{5}, \%\end{array}$} & \multirow{2}{*}{$\begin{array}{c}\text { Извле- } \\
\text { чение } \\
\mathrm{P}_{2} \mathrm{O}_{5}, \%\end{array}$} \\
\hline & MCTM* & кероснн & & & & \\
\hline$+0,28$ & 0,8 & 1,2 & $\begin{array}{l}\text { концентрат } \\
\text { хвосты } \\
\text { питание }\end{array}$ & $\begin{array}{r}53,2 \\
46,8 \\
100,0\end{array}$ & $\begin{array}{c}28,4 \\
1,05 \\
15,6\end{array}$ & $\begin{array}{r}96,8 \\
3,2 \\
100,0\end{array}$ \\
\hline$-0,28$ & $\begin{array}{l}0,6 \\
1,2\end{array}$ & $\begin{array}{l}1,2 \\
2,4\end{array}$ & $\begin{array}{l}\text { концентрат } \\
\text { хвосты } \\
\text { питание }\end{array}$ & $\begin{array}{r}55,9 \\
44,1 \\
100,0\end{array}$ & $\begin{array}{r}28,1 \\
0,6 \\
16,0\end{array}$ & $\begin{array}{r}98,3 \\
1,7 \\
100,0\end{array}$ \\
\hline
\end{tabular}

МСТМ - мыло сырого таллового масла.

концентрата имеют низкое содержание $\mathrm{P}_{2} \mathrm{O}_{5}$. Указанной картины не наблюдается при флотации аналогичной по верхней крупности руды Кингисеппского месторождения. Это объясняется, по-видимому, тем, что при одинаковой верхней крупности измельченного материала в руде Раквере наблюдается более высокое содержание в питании флотации крупных классов $+0,5$ и $+0,28$ мм, чем в кингисеппской руде, а следовательно, и более низкая (примерно на $10-12 \%$ ) их удельная поверхность. Вследствие этого количество собирателя, приходящееся на средние и тонкие классы, увеличивается и тем самым ухудшается селективность флотации этих классов. Снижать же общий расход собирателей нельзя, так как в этом случае резко возрастают потери $\mathrm{P}_{2} \mathrm{O}_{5}$ с хвостами, особенно с классами $+0,5$ мм, на которые приходится $40-70 \%$ потерь.

Из всех исследованных схем обогащения крупнозернистого материала, в том числе различных вариантов стадиальной флотации, оптимальные результаты дала схема с раздельной флотацией фракций $-0,8+0,28$ и $-0,28$ мм (рис. 4 , табл. 2 ).

Разделение измельченной руды на фракции по крупности 0,28 мм принято из тех соображений, что, во-первых, получаются близкие по выходу и содержанию $\mathrm{P}_{2} \mathrm{O}_{5}$ продукты, во-вторых, процесс флотации фракции $-0,28$ мм хорошо отработан и, наконец, на материале с узким диапазоном крупности частиц $(-1+0,28$ мм) может устойчиво работать любой аппарат для флотации крупнозернистого материала (машины с кипящим слоем, пенный сепаратор).

Таким образом, применение схемы с раздельной флотацией фракций $+0,28$ и $-0,28$ мм позволило получить кондиционные концентраты в обоих циклах при высоком операщионном извлечении $\mathrm{P}_{2} \mathrm{O}_{5}$. Кроме того, расход таллового масла и керосина в пересчете на руду составил соответственно 1,3 и $2,4 \mathrm{kr} / \mathrm{T}$, что на $10-20 \%$ ниже, чем при стандартной крупности измельчения.

\section{3. Катионная технология}

Накоплен большой опыт флотации ракушечных фосфоритов Маардуского месторождения с применением катионных собирателей $\left[{ }^{3}\right]$. Вместе с тем существенные различия вещественного состава руд Раквере и Маарду (содержание $\mathrm{P}_{2} \mathrm{O}_{5}$, крупность зерен кварца и др.) обусловили необходимость определения основных параметров катионной флотации представленных проб руды. С этой целью изучено влияние крупности 
питания, $\mathrm{pH}$ пульпы, реагентного режима на показатели флотации. В связи с тем, что руда Раквере содержит до 15\% крепко сцементированного материала и до $30 \%$ кварца находится в крупных труднофлотируемых классах +0,5 мм, требуется измельчение руды перед флотацией. Исходя из этого схема опытов включала измельчение, обесшламливание руды по крупности 40 мкм, флотацию с применением основного собирателя АНП-2 и других реагентов.

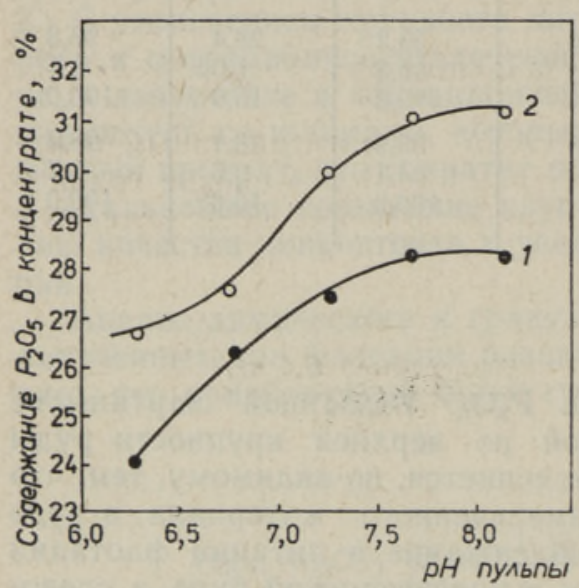

Рис. 5. Зависимость качества концентрата от $\mathrm{pH}$ пульпы при крупности питания флотации $-0,5$ (1) и $-0,4$ мм (2). Собиратель АНП-2 (расход 1,5 кг/т руды).

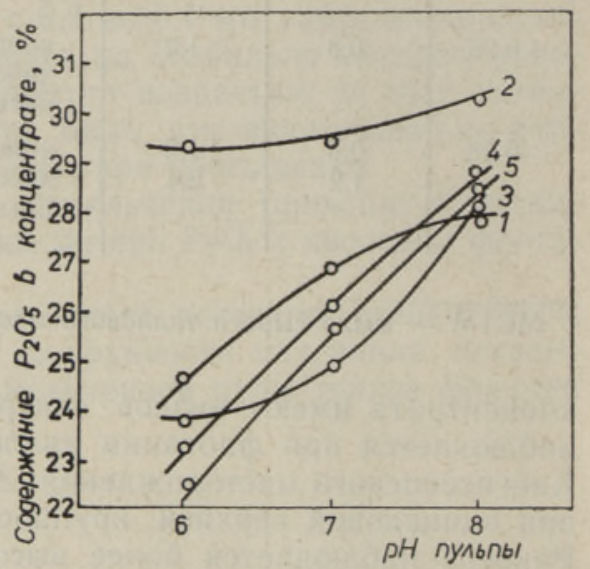

Рис. 6. Зависимость качества концентрата от $\mathrm{pH}$ пульпы при различных реагентных режимах: 1 - АНП-2 (1,0 кг/т); 2 - АНП-2 и лилафлот ККАс $(1,0$ и $0,1 \mathrm{kr} / \mathrm{T}) ; 3-\mathrm{AН \Pi -2}$ и КФН $(1,0$ и $0,1 \mathrm{\kappa r} / \mathrm{\tau}) ; 4$ - АНП-2 и КФН $(1,0$ и $0,2 \mathrm{\kappa r} / \mathrm{T}) ; 5-$ АНП-2 и КФН $(1,0$ и $0,3 \mathrm{kr} / \mathrm{T})$. Крупность питания флотации 0,5 мм.

Из результатов исследований (рис. 5 и 6 ) можно сделать следующие основные выводы:

1. При флотации кварца одним собирателем АНП-2 (1,5 кг/т) предпочтительным является более тонкое измельчение (не выше 0,4 мм). В этом случае получается кондиционный концентрат, однако потери $\mathrm{P}_{2} \mathrm{O}_{5}$ со шламами на $2-3 \%$ выше, чем при измельчении до $-0,5$ мм.

2. Введение в реагентный режим лилафлота KKАс или кремнефторида натрия (KФН) позволяет загрубить помол без ущерба для качества концентрата.

3. Режим с применением лилафлота ККАс практически нечувствителен к $\mathrm{pH}$ среды. Для других исследованных режимов оптимум $\mathrm{pH}$ находится в слабощелочной области $(7,8-8,3)$, являющейся естественной для пульпы, где твердая фаза представлена «чистой» рудой.

Кроме того, следует отметить, что выделенные перед флотацией шламы содержат $19-21 \% \mathrm{P}_{2} \mathrm{O}_{5}$ и могут быть утилизированы как фосмука либо как нейтрализующая добавка в производстве суперфосфата.

При выборе технологии для обогащения раквереских фосфоритов необходимо учитывать следующие факторы.

Технология на основе анионных собирателей обеспечивает более высокое (на 5-6\%) извлечение $\mathrm{P}_{2} \mathrm{O}_{5}$ в концентрат и шламы (в случае их утилизации), однако нуждается в более широком ассортименте реагентов (полярный и аполярный собиратели, каустическая и кальцинированная сода, жидкое стекло), большинство из которых остродефицитны (талловое масло, керосин, сода). Из опыта Кингисеппской обо- 
ғатительной фабрики известно также, что такая технология приводит к сильному зарастанию флотомашин и трубопроводов осадком, образующимся в результате взаимодействия руды с органикой (керосин, талловое масло). Более высокие расходы указанных реагентов для флотации руд Раквере усугубят положение. С другой стороны, необходимость использования хвостов флотации для закладки выработанного пространства требует отдать предпочтение анионной технологии, так как в этом случае твердая фаза хвостов несет в себе меньше сорбированных реагентов, чем при катионной флотации.

\section{4. Переработка магнезиальных руд}

Согласно последним исследованиям ГИГХСа, к магнезиальным относятся руды с модулем магнезиальности выше 0,1 . Более низкое граничное значение модуля по сравнению с таковым для кингисеппских руд

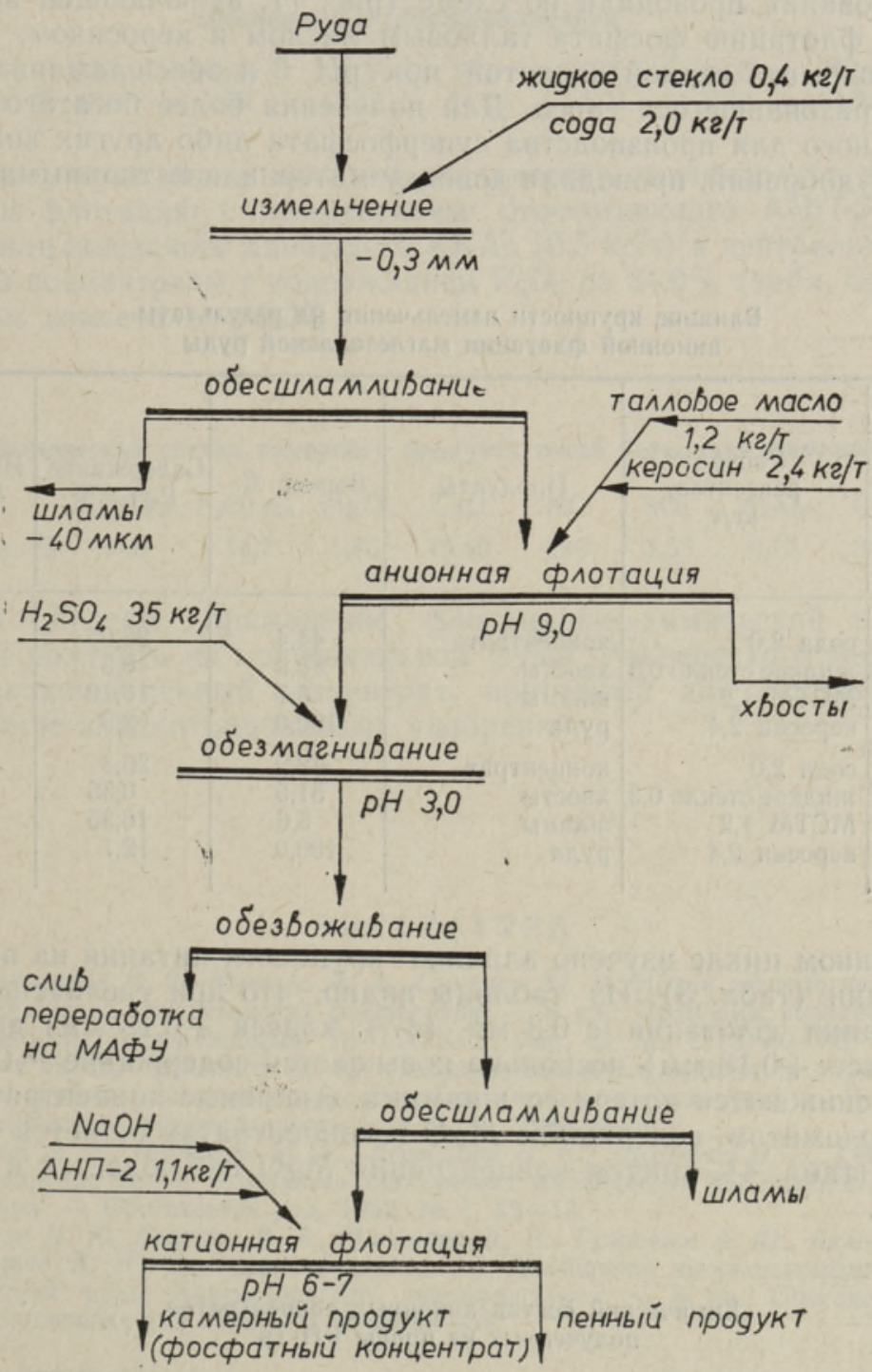

Рис. 7. Схема флотационно-химического обогащения руды Раквереского месторождения МАФУ - магний-аммонийфосфатное удобрение. 
объъянняется, по-видимому, тем, что карбонатные-минералы Раквере имеют ряд специфических особенностей (замещение части магния железом и др.), которые могут привести к повышению флотоактивности доломита при использовании анионных собирателей, а тем самым и к более интенсивному переходу $\mathrm{MgO}$ в концентрат.

Обогатимость магнезиальных руд изучена на пробах VII-Tp, VIII-Tp и X-Тр с модулями от 0,12 до 0,24 . Попытки обогащения таких руд только флотационным методом с применением селективных собирателей (типа ацилированных аминокислот) позволили получить $29 \%$-ный по $\mathrm{P}_{2} \mathrm{O}_{5}$ концентрат, однако, содержание $\mathrm{MgO}$ в нем составило 3,5$4,5 \%$.

В целях получения кондиционных по $\mathrm{MgQ}$ концентратов испытана разработанная для кингисеппских магнезиальных руд комбинированная флотационно-химическая технология, обеспечившая, по данным полупромышленных испытаний, успешное обогащение руд с модулем магнезиальности $0,13-0,20\left[{ }^{4}\right]$.

Исследования проводили по схеме (рис. 7), включающей измельчение руды, флотацию фосфата талловым маслом и керосином, выщелачивание доломита серной кислотой при $\mathrm{pH} 3$ и обесшламливание для вывода образовавшегося гипса. Для получения более богатого продукта, пригодного для производства суперфосфата либо других концентрированных удобрений, проводили доводку материала катионными собирателями.

Таблица 3

Влияние крупности измельчения на результаты анионной флотации магнезиальной руды

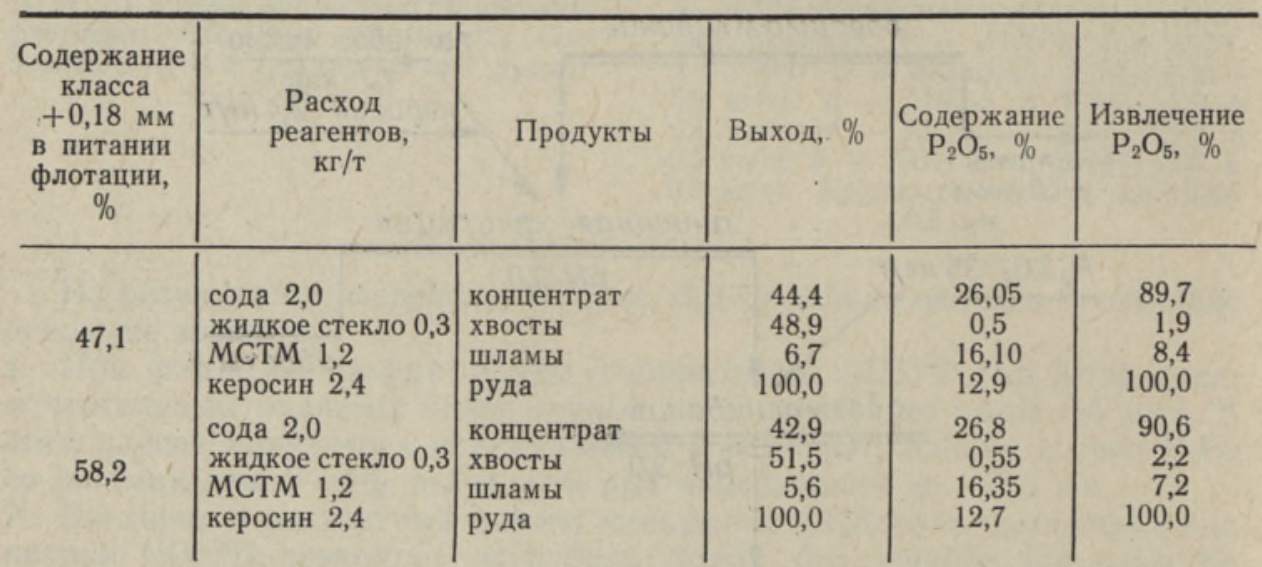

В анионном цикле изучено влияние крупности питания на показатели флотации (табл. 3). Из таблицы видно, что при увеличении крупности питания флотации с 0,3 мм $(47 \%$ класса $+0,18$ мм $)$ до 0,5 мм $\left(58 \%\right.$ класса $+0,18$ мм) несколько повышается содержание $\mathrm{P}_{2} \mathrm{O}_{5}$ в концентрате, снижаются потери со шламами. Анионные концентраты разубожены доломитом, содержание $\mathrm{MgO}$ в концентратах остается на уровне $3,75 \%$ (табл. 4), причем концентрация $\mathrm{MgO}$ наблюдается в классах $-0,18$ мм.

Таблица 4

Химический состав анионных концентратов, полученных из пробы VII-Tр

$\begin{array}{lcccccccc}\text { Компонент } & \mathrm{P}_{2} \mathrm{O}_{5} & \mathrm{MgO} & \mathrm{CaO} & \mathrm{HO} & \mathrm{SO}_{3} & \mathrm{Al}_{2} \mathrm{O}_{3} & \mathrm{CO}_{2} & \mathrm{Fe}_{2} \mathrm{O}_{3} \\ \text { Содержание, \% } & 26,4 & 3,75 & 41,79 & 11,75 & 0,78 & 0,41 & 8,29 & 1,92\end{array}$


Анионные концентраты с высоким содержанием $\mathrm{MgO}$, полученные при различной крупности измельчения, далее подвергали химическому обогащению (обезмагниванию), которое проводили при следующих параметрах: pH 3,0 (расход серной кислоты $35 \mathrm{kr} / \mathrm{T}$ ), температура процесса $70-80^{\circ} \mathrm{C}$, время контактирования с кислотой $40-45$ мин, соотношение твердой и жидкой фаз $1: 4$. Жидкая фаза после выщелачивания содержит $0,15-0,2 \% \quad \mathrm{P}_{2} \mathrm{O}_{5}, 0,54-0,6 \% \mathrm{MgO}$, извлечение $\mathrm{MgO}$ в жидкую фазу составило $62,2-65,6 \%$, потери $\mathrm{P}_{2} \mathrm{O}_{5} 2,5 \%$. После выщелачивания концентраты подвергали обесшламливанию для удаления образовавшегося мелкокристаллического гипса. Эта операция позволила повысить содержание $\mathrm{P}_{2} \mathrm{O}_{5}$ с 26,4 до $30,3 \%$ при операционном извлечении $90,0-94,0 \%$. Содержание $\mathrm{MgO}$ в концентратах при химическом обогащении снижается до $1,65 \%$ (табл. 5 ).

Таблица 5

\section{Химический состав концентрата после химического обогащения и обесшламливания}

$\begin{array}{lcccccccc}\text { Компонент } & \mathrm{P}_{2} \mathrm{O}_{5} & \mathrm{MgO} & \mathrm{CaO} & \mathrm{HO} & \mathrm{SO}_{3} & \mathrm{Al}_{2} \mathrm{O}_{3} & \mathrm{CO}_{2} & \mathrm{Fe}_{2} \mathrm{O}_{3} \\ \text { Содержание, } \% & 30,3 & 1,65 & 42,62 & 14,87 & 1,01 & 0,14 & 4,24 & 1,67\end{array}$

Для получения более высоких по качеству концентратов проводили катионную флотацию с применением отечественного АНП-2 (расход $1,1 \mathrm{kr} / \mathrm{T})$ или шведского лилафлота ККАс $(0,5 \mathrm{kr} / \mathrm{T})$ в нейтральной среде. Получены концентраты с содержанием $\mathrm{P}_{2} \mathrm{O}_{5}$ до $34,0 \%$ (табл. 6 ) при операционном извлечении $90,0 \%$.

\section{Таблица 6}

\section{Химический состав камерного продукта после катионной флотации}

$\begin{array}{lccccccccc}\text { Компонент } & \mathrm{P}_{2} \mathrm{O}_{5} \text { общ } & \mathrm{P}_{2} \mathrm{O}_{5} \text { усв } & \mathrm{MgO} & \mathrm{CaO} & \mathrm{HO} & \mathrm{SO}_{3} & \mathrm{Al}_{2} \mathrm{O}_{3} & \mathrm{CO}_{2} & \mathrm{Fe}_{2} \mathrm{O}_{3} \\ \text { Содержание, } \% & 33,9 & 16,7 & 1,30 & 49,49 & 4,30 & 1,55 & 0,13 & 3,97 & 1,75\end{array}$

Таким образом, применение флотационно-химической технологии позволяет получать из магнезиальной руды Раквереского месторождения высококачественный концентрат, пригодный для использования в производстве концентрированных удобрений.

\section{Л ИТЕРАТУРА}

1. Цуцульковский В. Я., Юркова Л. А., Смирнов Ю. М. Новая технологическая схема обогащения кингисепцских фосфоритов. - В кн.: Проблемы разработки Кингисеппского месторождения. Тр. ГИГХСа, вып. 43. М., 1978, 60-65.

2. Татарский A. E., Артеменко M. Ю. Полупромышленные испытания схемы обогащения грубоизмельченной руды Кингисеппского месторождения. - В кн.: Горнохимическая промышленность, вып. 2. М., 1983, 5-6.

3. Татарский А. Е., Подвигин М. А., Шувалова Н. К., Суханова В. Г., Губанов А. Ф. Внедрение новой технологии обогащения фосфоритов Маардуского месторождения. - Обогащение руд, 1982, № 1, 12-13.

4. Шувалова Н. К., Беляков В. А., Макарова Л. П., Румянцев А. Ю., Бельченко Г. В., Ершов В. И. Флотационно-хнмическое обогащение высокомагнезиальной фосфатной руды Кингисеппского месторождения. - В кн.: Обогащение тонковкрапленных руд. Апатиты, 1985, 56-58.

Государственный

научно-исследовательский институт горно-химического сырья
Поступила в редакцию

28/XI 1985 


\section{RAKVERE LEIUKOHA FOSFAATMAAKIDE RIKASTATAVUŚ}

Rakvere fosforiitide ainelise koostise ja rikastatavuse uurimise tulemusel on täpsustatud maakide magnesiaalsusmooduli kriitiline väärtus. Vähemagnesiaalsete maakide puhul soovitatakse kasutada jämedateralise materjali rikastamist, mis tagab protsessi tehnilismajanduslike näitajate paranemise.

Maake, mille magnesiaalsuse mooduli väärtus on üle 0,1 , on otstarbekas rikastada kombineeritud flotokeemilise tehnoloogia järgi. Saadav kõrgekvaliteediline kontsentraat sobib kontsentreeritud väetiste valmistamiseks.

\section{N. SHUVALOVA, A. TATARSKY, L. MAKAROVA,}

T. RACHKOVSKAYA, N. RODINA, G. FYODOROV

\section{THE ENRICHMENT OF RAKVERE PHOSPHATE ORES}

The critical value of the ore magnesian module has been determined as a result of the investigation of the elemental analysis and the enrichment of Rakvere phosphorites. The enrichment scheme of coarse-grained material for the low-magnesian ores has been suggested. It guarantees the improvement of the technical and economic parameters of the process.

The combined flotation-chemical methods can be efficiently applied for the enrichment of phosphorites with the ore magnesian module value more than 0.1. The obtained highquality concentrate is suitable for producing concentrated fertilizers. 